\title{
The freedom to excel: Belief in free will predicts better academic performance
}

Citation for published version (APA):

Feldman, G., Chandrashekar, S. P., \& Wong, K. F. E. (2016). The freedom to excel: Belief in free will predicts better academic performance. Personality and Individual Differences, 90, 377-383.

https://doi.org/10.1016/j.paid.2015.11.043

Document status and date:

Published: 01/02/2016

DOI:

10.1016/j.paid.2015.11.043

Document Version:

Accepted author manuscript (Peer reviewed / editorial board version)

Document license:

CC BY-NC-ND

\section{Please check the document version of this publication:}

- A submitted manuscript is the version of the article upon submission and before peer-review. There can be important differences between the submitted version and the official published version of record.

People interested in the research are advised to contact the author for the final version of the publication, or visit the DOI to the publisher's website.

- The final author version and the galley proof are versions of the publication after peer review.

- The final published version features the final layout of the paper including the volume, issue and page numbers.

Link to publication

\footnotetext{
General rights rights.

- You may freely distribute the URL identifying the publication in the public portal. please follow below link for the End User Agreement:

www.umlib.nl/taverne-license

Take down policy

If you believe that this document breaches copyright please contact us at:

repository@maastrichtuniversity.nl

providing details and we will investigate your claim.
}

Copyright and moral rights for the publications made accessible in the public portal are retained by the authors and/or other copyright owners and it is a condition of accessing publications that users recognise and abide by the legal requirements associated with these

- Users may download and print one copy of any publication from the public portal for the purpose of private study or research.

- You may not further distribute the material or use it for any profit-making activity or commercial gain

If the publication is distributed under the terms of Article $25 \mathrm{fa}$ of the Dutch Copyright Act, indicated by the "Taverne" license above, 
This work is licensed under the Creative Commons Attribution-NonCommercial-NoDerivatives 4.0 International License. To view a copy of this license, visit http://creativecommons.org/licenses/by-nc-nd/4.0/

The Freedom to Excel: Belief in Free Will

Predicts Better Academic Performance

\author{
Gilad Feldman \\ Department of Work and Social Psychology \\ Maastricht University \\ Maastricht, 6200MD, The Netherlands \\ giladfel@gmail.com
}

Prasad Chandrashekar

Department of Management

Hong Kong University of Science and Technology

Clearwater Bay, Kowloon, Hong Kong SAR

spc@ust.hk

Kin Fai Ellick Wong

Department of Management

Hong Kong University of Science and Technology

Clearwater Bay, Kowloon, Hong Kong SAR

mnewong@ust.hk 


\section{Acknowledgements}

Preparation of this article was supported by the RGC General Research Fund (HKUST 644312) and UGC Infra-Structure Grant (SBI14BM23) awarded to Kin Fai Ellick Wong. 
Highlights:

- Two studies demonstrated the relationship between the belief in free will and academic performance.

- In Study 1 , belief in free will predicted better academic task performance on a spell checking task.

- In Study 2, a time-lagged study in real academic settings, belief in free will predicted better academic grades.

- Belief in free will is a significant unique predictor of academic achievement, beyond implicit theories and self-control. 


\begin{abstract}
Increasing evidence supports the importance of beliefs in predicting positive outcomes in life. This study examines the performance implications of the belief in free will as an abstract, philosophical belief that views the self as free from internal and external constraints and capable of choosing and directing one's own path. In Study $1(\mathrm{~N}=116$, undergraduates), belief in free will was associated with higher performance on an academic proofreading task. In Study $2(\mathrm{~N}=$ 614, undergraduates), we examined performance in real academic settings, and the belief in free will measured at the beginning of the semester predicted better course and semester grades at the end of the semester. Importantly, we found support for the distinctive contribution of the belief in free will in comparison to well-established predictors of academic performance - trait selfcontrol and implicit theories. We conclude that individual differences in the endorsement of the belief in free will are a significant and unique predictor of academic achievement.
\end{abstract}

Keywords: academic performance; belief in free will; beliefs; task performance 


\section{The Freedom to Excel: Belief in Free Will \\ Predicts Better Academic Performance}

The last two decades have witnessed the emergence of research that recognized the importance of beliefs as predictors of academic achievement (Hong, Chiu, Dweck, Lin, \& Wan, 1999; Yeager \& Dweck, 2012). Beliefs have been identified as essential components of selfconcept as they affect sense-making and shape the meaning given to all aspects of life, and therefore play a crucial role in guiding behavior (Dweck, 2008). People differ in their beliefs, and these differences hold the potential for predicting differences in behavior and outcomes (Dweck, 2014). This is especially true for undergraduates attending college because students often face difficult challenges and important choices under intense pressure to perform. Academic performance is dependent on the ability to change, adapt, make difficult decisions, and learn from mistakes, yet these are rooted in associated beliefs that change is controlled and choice is free.

A promising direction in social psychology and experimental philosophy explores agency-related philosophical beliefs and focuses on views regarding free will and determinism. People differ in their beliefs regarding the human capacity for choice; some view their behaviors and lives as a consequence of their own agentic free choice, whereas others believe that they are deterministically guided by internal factors that are beyond their control, such as their upbringing, personality, or genetics, or by externals factors such as God, nature, science, or fate (Baumeister, 2008). This abstract philosophical belief in free will encompasses a broad view of the person as an active agent who is capable of choosing one's own path, planning for long-term 
goals, changing if so desired, and directing one's own actions to achieve desired goals. Previous literature on the relationship between beliefs and performance has mainly focused on implicit theories; specifically, the contrast between two groups of people endorsing opposing implicit theories based on essentialism - entity theorists who consider human attributes as relatively fixed and incremental theorists who view such attributes as malleable (Dweck, 2008, 2012). These two types of people differ in their view of whether change is at all possible, yet this categorization does not address the broader question of how change occurs and the role that the self plays in making a desired change happen, which is conceptualized by the belief regarding free will. The present work aims to extend previous research on the effect of beliefs on academic performance by theorizing and testing the hypothesis that the belief in free will would predict better academic performance.

\section{Belief in free will}

The belief in free will is a core belief that views humans as free from both external constraints (e.g., luck, fate, God, the environment, society, other agents) and internal deterministic factors (e.g., urges, needs, genes, personality, affect). The belief in free will is common in most modern societies and religions and is held by a high percentage of people across the world (Sarkissian et al., 2010). Nevertheless, people differ in the degree to which they endorse this belief (Carey \& Paulhus, 2013; Paulhus \& Carey, 2011). The growing prevalence of this belief supports the philosophical idea that the belief in free will serves an important, positive, and functional role for the self in adaptation and survival (Brembs, 2011), the pursuit of what a person wants or needs (Dennett, 2003; Hume, 1748), and the coordination with others in

society (Baumeister, 2008; Kant, 1788/1997). The concept of free will has long been theorized as underlying important aspects of human action, such as the attribution of intentionality (Roskies, 
2006), the understanding of moral responsibility (Stillman, Baumeister, \& Mele, 2011), the acceptance of accountability (Nietzsche, 1886/1966), as well as of perceived ability, selfregulation, and the drive for action (Greve, 2001).

Studies have shown that belief in free will has broad implications for behavior (Brass, Lynn, Demanet, \& Rigoni, 2013). The concept of free choice develops very early on in life (Kushnir, 2012; Kushnir, Wellman, \& Chernyak, 2009; Nichols, 2004) across cultures (Chernyak, Kushnir, Sullivan, \& Wang, 2013), with behavioral implications as early as preschool (Chernyak \& Kushnir, 2014). People who believe in free will learn better from their own mistakes and misdeeds (Stillman \& Baumeister, 2010), have higher perceived ability and positive attitudes toward decision making (Feldman, Baumeister, \& Wong, 2014), enjoy greater self-efficacy and suffer less from helplessness (Baumeister \& Brewer, 2012), show more honest behavior (Vohs \& Schooler, 2008), demonstrate higher levels of autonomy and report higher willingness to exert effort (Alquist, Ainsworth, \& Baumeister, 2013), show stronger motivations for career success and exhibit better job performance (Stillman et al., 2010), and are more futureoriented (Seligman, Railton, Baumeister, \& Sripada, 2013). The belief in free will has even been shown to affect the fundamental processes of agentic volition (Rigoni \& Brass, 2014), such as increased voluntary motor preparation (Rigoni, Kühn, Sartori, \& Brass, 2011), better suppression of automatic pain reactions (Lynn, Van Dessel, \& Brass, 2013), and more efficient neural reactions to errors (Rigoni, Pourtois, \& Brass, 2014; Rigoni, Wilquin, Brass, \& Burle, 2013). These findings support the view that the belief in free will has evolved to facilitate both the individual pursuit of long-term goals and the coexistence with others within cultures (for a review, see Baumeister \& Monroe, 2014). 


\section{Belief in free will and academic performance}

The belief in free will is highly relevant to academic achievements because universities present students with numerous challenges, decisions needed for possible change and improvement, as well as ongoing feedback about their performance. In college environment, students typically enjoy a high level of discretion in setting their personal goals and arranging their daily activities. Students frequently face day-to-day motivational conflicts contrasting choices between short-term temptations and long-term goals (e.g., choosing between academic tasks and leisure activities; Fries, Dietz, \& Schmid, 2008; Grund, Brassler, \& Fries, 2014). Moreover, college life is not only about academic learning, but it is also a stage in life that symbolizes independence. During this period, many students experience their first separation from their parents, search for their unique voice, and develop their own individual identities (Stephens, Townsend, Markus, \& Phillips, 2012).

The belief in free will encompasses the perceptions of human volitional capabilities and serves as an evolved mechanism for directing independent action in a complex social environment (Alquist et al., 2013; Baumeister \& Monroe, 2014) such as that of college. Those who believe in free will are motivated to pursue long-term functional goals (Seligman et al., 2013; Stillman et al., 2011) and show more consideration for the consequences of their actions. The belief in free will encourages goal monitoring and facilitates enhanced learning from one's mistakes to improve future performance (Alquist, Ainsworth, Baumeister, Daly, \& Stillman, 2015), all crucial aspects of academic achievement.

The belief in free will also aids in dealing with the burden of choice and coping with decision situations. To be able to make choices effectively, it is essential that one perceives that 
choices are available and that the self is capable of making a choice (Baumeister, Sparks, Stillman, \& Vohs, 2008; Monroe \& Malle, 2010). Those who believe in free will consider their own actions as more driven by their own volitional choice, are more motivated to choose, and report higher enjoyment of having choice and of the outcomes of their choices (Feldman et al., 2014). Thus, once faced with a certain outcome, those who believe in free will are likely to assume more responsibility, learn better from their mistakes, and work harder toward changing negative outcomes. The perception of choice, positive attitudes toward choice, and the ability to make choices that are affected by the belief in free will are all essential components for success in academic tasks and in college life (Patall, Cooper, \& Robinson, 2008; Patall, Cooper, \& Wynn, 2010).

Our central premise is that the belief in free will would be related to positive academic outcomes. Thus far, much of the literature exploring the relationship between beliefs and academic achievement has focused on implicit theories, mostly overlooking agentic beliefs. Conceptual and empirical differences between the belief in free will and implicit theories have previously been noted (Crescioni, Baumeister, Ainsworth, Ent, \& Lambert, 2015; Dweck \& Molden, 2008) - Implicit theories focus on whether a change in human behavior is possible and whether human attributes are fixed (race, intelligence, etc.; Dweck, 2006, 2008), whereas the belief in free will captures the agentic aspects of the capacity for the self to freely choose and direct behavior and change (see Study 2 for more details and an empirical demonstration). In the present investigation, we also sought to establish the unique contribution of the belief in free will above and beyond implicit theories. 


\section{The present investigation}

In two studies, we examine the relationship between the belief in free will and academic performance with the expectation that individual differences in the endorsement of the philosophical notion of free will would predict better academic performance. We first tested the hypothesis by exploring the belief in free will as a predictor of performance on a short proofreading task (Study 1). In a subsequent study (Study 2), we tested the relationship between the belief in free will and undergraduates' academic performance in a real-life university context.

\section{Study 1: Academic task performance}

Study 1 was constructed to provide a first test of the hypothesis that the belief in free will would predict better academic performance by assessing its association with a simple spellchecking task typical in an academic context.

\section{Method}

Procedure and participants. A total of 116 undergraduate students from a university in Hong Kong participated in return for course credit $\left(M_{\text {age }}=19.18, S D_{\text {age }}=.65 ; 52.6 \%\right.$ females; 84 Hong Kong locals, 16 mainland Chinese, 16 international students). The participants reported their belief in free will and then proceeded to a spell-checking task (adapted from Lee, Gino, \& Staats, 2014) that included 16 science essay sentences with varying numbers of spelling mistakes. The participants were instructed to find and report as many errors as possible. Spelling performance tasks are often utilized as a measure of basic academic skills, and are included in various achievement tests used in educational settings. For example, spelling performance is included in the Wide Range Achievement Test (WRAT; 2001), which is often adopted as a proxy for academic achievement in the literature (e.g., Mayes, Calhoun, Bixler, \& Zimmerman, 2009; 
Rohde \& Thompson, 2007). The spelling performance task was particularly relevant to the students in this sample because English is a second language for most Hong Kong undergraduate students, with Cantonese Chinese as the native language for Hong Kong locals and Mandarin Chinese for students from mainland China. All of the undergraduate studies at the university sampled are conducted in English, where the ability to accurately and efficiently read, understand, and proof English words and sentences is an important element of the undergraduates' learning demands. In this context, proofreading and spelling are crucial skills for undergraduate students to master so that they would effectively prepare essays and answer exams under high-pressure time constraints.

Measures. Belief in free will. The belief in free will was measured using a slider on a single item "Do you have free will?" (0 - I do not have free will; 100 - I have free will). This item has been shown to be an effective measure of the belief in free will, with high loading on the belief in free will factor within the free will scales (see Carey \& Paulhus, 2013, regarding the use of single items in measuring beliefs).

Task performance. Task performance was measured using two indices, namely, the number of spelling mistakes detected and a time measure calculated by a log transformation of the average time spent on the task divided by the number of spelling mistakes correctly identified (Lee et al., 2014).

\section{Results and Discussion}

The correlations between the measures are provided in Table 1. The three student populations showed a significant difference in their belief in free will (Hong Kong: $M=66.92$, $S D=19.46$; mainland China: $M=64.06, S D=21.45$; international students: $M=80.13, S D=$ 
$14.73 ; F(2,113)=3.65, p=.029)$, indicating cross-cultural variations in the endorsement of the belief in free will. The student groups also varied in the number of correctly identified spelling mistakes (Hong Kong: $M=2.08, S D=.24$; mainland China: $M=1.89, S D=.47$; foreign students: $M=2.01, S D=.26 ; F(2,112)=3.09, p=.05)$ and the time spent in completing the task (Hong Kong: $M=2.64, S D=.28$; mainland China: $M=2.74, S D=.25$; foreign students: $M=$ $2.48, S D=.29 ; F(2,112)=3.54, p=.032)$. The relationship between the belief in free will and spell-checking performance was significant. Participants who reported a stronger belief in free will correctly identified more spelling mistakes $(r=.20, p=.033)$ and did so in less time $(r=$ $-.20, p=.029)$. Multiple-regression analyses showed similar results for the number of correctly identified mistakes after controlling for age, gender, and country of origin $\left(\beta=.20, \Delta R^{2}=.04, p\right.$ $=.032 ; F(5,109)=2.89, p=.017)$, and slightly weaker results for time $\left(\beta=-.17, \Delta R^{2}=.03, p\right.$ $=.077 ; F(5,109)=2.44, p=.039)$.

Study 1 supported our hypothesis. The belief in free will predicted better performance on an academic task. The task measured was anonymous and without any extrinsic motivations or personal consequences. Study 2 was designed to extend the findings to a more complex measure of academic performance that also captures a sustained academic effort over a long period and holds personal consequences for the person.

\section{Study 2: Academic performance}

Study 2 extends Study 1 in several aspects. First, we assessed actual academic performance by measuring undergraduate course and overall semester performance over time, rather than performance on a simple singular academic task. Second, we measured the belief in free will more comprehensively using a well-validated scale. Third, the effect of the belief in free 
will for performance was compared to effects of trait self-control and implicit theories (discussed below), two related concepts that have been well-established as predictors of positive outcomes (Burnette, O'Boyle, VanEpps, Pollack, \& Finkel, 2013; de Ridder, Lensvelt-Mulders, Finkenauer, Stok, \& Baumeister, 2012; Duckworth \& Seligman, 2005; Yeager et al., 2014). In a time-lagged design, the students reported their belief in free will, trait self-control, and implicit theories at the beginning of the semester, and the data were used as predictors for student performance throughout the semester.

\section{Pretest: Belief in free will as a unique predictor}

We argued for the belief in free will as a unique predictor of academic performance. We began with a pretest to empirically establish this conceptual argument. Below we briefly discuss some of the conceptual differences and relationships between the belief in free will, implicit theories, and trait self-control, followed by an empirical pretest.

Several important differences exist between implicit theories and the belief in free will. Implicit theorists focus on malleability, which indicates whether the person believes that change in fundamental human attributes is possible. These implicit theories regarding change provide meaning for the relationship between behavior and outcomes, thereby affecting striving and pursuit of change (Dweck \& Leggett, 1988; Dweck, Chiu, \& Hong, 1995; Dweck, 1999; Hong et al., 1999). By contrast, the belief in free will focuses on the capacity for choice and the assumption of responsibility, which identifies whether a choice is made based on one's own volition or is determined by other causal factors. The belief in free will considers all of the causal determinants as equally important, whereas each of the implicit theories focuses on and emphasizes one specific domain of the self (e.g., intelligence, personality, etc.). For example, 
racial implicit theories focus on racial categories and argue that whether people view race as malleable or not is crucial to how they explain the behavior of people with regard to their racial category. By contrast, determinists would consider race or any other essentialized category as only one of many factors that limits one's ability to deviate from predictable behavior. Furthermore, incrementalists' implicit belief that a category (e.g., one's intelligence) is malleable does not imply that they perceive themselves as being able to choose when and how to change, nor do these beliefs address any potential external constraints. Therefore, we expect that the belief in free will would predict performance above and beyond implicit theories due to the broader view of the person and in addressing a wider set of potential constraints on possible change - internal, external, and in all of the domains simultaneously.

Conceptual connections exist between the belief in free will and the construct of trait selfcontrol in the context of goal pursuit and performance. Self-control refers to "an agent's capacity to sustain, stop, amplify, or otherwise modify an incipient or unwanted response or action" (Haggard, Mele, O'Connor, \& Vohs, 2010) and is associated with a conscious effort by an agent to exert energy (effort) to resist temptation and overcome oneself (affect, cognition, and behavior). Items measuring the trait self-control measure self-discipline and concentration, and the ability to avoid distractions and effectively work toward long-term goals (e.g., Tangney, Baumeister, \& Boone, 2004). Hence, trait self-control focuses on regulating the self and opposing urges and desires, whereas the belief in free will is about one's generalized belief in the freedom of action and the perceived capacity to choose one's own actions or to do otherwise (Baumeister, 2008). Studies have indeed shown that the belief in free will is associated with better self-control (Rigoni, Kühn, Gaudino, Sartori, \& Brass, 2012; Rigoni et al., 2013). Linking the two constructs, we can conceptualize belief in free will as the perceived capacity of whether 
or not and in what manner to exert self-control in different situations (Rigoni et al., 2012; Wertenbroch, Vosgerau, \& Bruyneel, 2008), such that the belief in free will facilitates pointing the self in a desired direction, whereas trait self-control facilitates the long pursuit of this direction.

A total of 98 participants were recruited online using Amazon Mechanical Turk for US\$0.30. Fifteen participants failed more than one attention check and were therefore removed from the analysis, leaving a sample of 83 participants $\left(33\right.$ females; $\left.M_{\text {age }}=33.99, S D_{\text {age }}=12.28\right)$. We measured the belief in free will (Rakos, Steyer, Skala, \& Slane, 2008), implicit theories (Dweck, 1999; Chao, Hong, \& Chiu, 2013), and trait self-control (Tangney et al., 2004). The scale details are available in the methods section for Study 2 below.

The correlations and reliabilities for the pretest are provided in Table 2 . The belief in free will strongly correlated with trait self-control $(r=.49, p<.001)$ and exhibited a significantly weaker relationship with implicit theories $(r=.02$ to $r=-.25)$. We performed confirmatory factor analyses to examine whether a model, including the belief in free will and other constructs assessed, yields a better fit than a model with each of the other constructs as separate. The analysis showed a significantly better fit for the belief in free will scale as a separate construct than the inclusion of the belief in free will together with trait self-control or implicit theories as one single factor (self-control: two factor $\chi=450.97$, one factor $\chi=501.27$, Diff $\chi=50.30, p$ $<.001$; implicit theories: two factor $\chi=271.07$, one factor $\chi=395.26$, Diff $\chi=124.19, p<.001$ ). These findings support the previous theoretical and empirical differentiation of the belief in free will as a unique construct from trait self-control and implicit theories. 


\section{Method}

Procedure and participants. A total of 614 undergraduate students at a university in Hong Kong participated for course credit $\left(M_{\text {age }}=18.90,54.6 \%\right.$ female, 438 from Hong Kong, 92 from mainland China, and 84 international students). The students completed questionnaires on the belief in free will and trait self-control at the beginning of the semester, and these questionnaires were later matched against the students' grades in a core undergraduate course. The course was taught by five different professors in 10 different sections using similar syllabuses and course structures. The overall semester GPAs were later obtained for 518 of the students who successfully completed the semester $\left(M_{\text {age }}=18.84 ; 58 \%\right.$ females $)$.

\section{Measures}

Belief in free will. The belief in free will was measured using the eight-item self subscale of the Free Will and Determinism Scale (FWD scale, Rakos et al., 2008). The items refer to oneself as having free will, such as "I am in charge of my actions even when my life's circumstances are difficult," and "I have free will" ( $1=$ not true at all to $5=$ always true $)$.

Implicit theories. Eight items assessed implicit theories regarding the general capacity for change (Dweck, 1999; e.g., "The kind of person people is, is something very basic about them, and it can't be changed very much" and "As much as I hate to admit it, you can't teach an old dog new tricks. People can't really change their deepest attributes"), and three items assessed implicit theories regarding intelligence (e.g., "You have a certain amount of intelligence and you really can't do much to change it") measured on a scale of 1 (Strongly disagree) to 6 (Strongly agree).

Self-control. Self-control was measured using the short version of the Self-Control Scale (SCS, Tangney et al., 2004). The scale includes 13 statements, such as "I am good at resisting 
temptation," and "People would say that I have iron self-discipline" $(1=$ not at all to $5=$ very much), which were averaged into a single self-control score.

Course performance. Performance was reported by the instructors at the end of the semester. To eliminate possible differences in scoring, all of the scores were standardized within each of the 10 class sections.

Overall GPA performance. GPAs indicating the overall performance of the students across all of the courses taken that semester (ranging from 0 to 4.3 ) were obtained at the end of the semester.

Demographics. Age, gender, and country of origin were collected as control variables together with the other scales at the beginning of the semester.

\section{Results and Discussion}

Correlations between the measures are detailed in Table 3. The two performance measures were very highly correlated $(r=.73, p<.001)$. The belief in free will exhibited a positive correlation with the final course grade $(\mathrm{N}=614 ; r=.08, p=.043)$ and an effect of a similar size on the overall GPA of the semester $(\mathrm{N}=518 ; r=.09, p=.035)$. The three student populations showed a significant difference in belief in free will $(\alpha=.71$; Hong Kong: $M=3.45$, $S D=.42$; mainland China: $M=3.49, S D=.44$; foreign students: $M=3.80, S D=.46 ; F(2,611)=$ $23.80, p<.001$ ), indicating cross-cultural differences in the endorsement of the belief in free will. The student groups also varied in performance (course - Hong Kong: $M=-.05, S D=.92$; mainland China: $M=.36, S D=.91$; foreign students: $M=-.11, S D=1.32 ; F(2,611)=7.20, p$ $=.001$; semester - Hong Kong: $M=2.84, S D=.53$; mainland China: $M=3.11, S D=.53$; foreign students: $M=2.90, S D=.57 ; F(2,515)=7.99, p<.001)$. 
The belief in free will was positively correlated with trait self-control $(r=.19, p<.001)$ and negatively correlated with implicit theories (General: $r=-.12, p=.004$; Intelligence: $r=$ $-.24, p<.001)$. Compared with trait self-control and implicit theories, the belief in free will was the only predictor to demonstrate significant positive correlations with both performance measures. Trait self-control was positively correlated with the final course grade $(r=.09, p$ $=.024$; GPA: $r=.06, p=.158 \mathrm{~ns})$, and implicit theories were positively correlated with the semester GPA $(r=.11, p=.016$; course grade: $r=.03, p=.476 \mathrm{~ns})$.

A hierarchical regression analysis controlling for age, gender, and country of origin showed that the belief in free will was a significant predictor of final course performance $(F(5$, $\left.608)=4.24, p<.001 ; \beta_{\mathrm{BFw}}=.10, p=.022, \mathrm{CI}[.03, .40] ; R^{2}=.03 ; \Delta R^{2}=.01\right)$ and $\operatorname{GPA}(F(5,512)$ $\left.=5.20, p<.001 ; \beta_{\mathrm{BFW}}=.10, p=.021, \mathrm{CI}[.02, .24] ; R^{2}=.05 ; \Delta R^{2}=.01\right)$. The included controls did not significantly affect the relationship. We also tested for the effect of the course sessions and instructors, but none of the interactions were significant. The effect remained even when further controlling for implicit theories and trait self-control (Course grade: $F(11,602)=2.30, p=.009$; $\beta_{\mathrm{BFW}}=.09, p=.046, \mathrm{CI}[.003, .38] ; R^{2}=.04 ; \Delta R^{2}=.01 ; \mathrm{GPA}: F(7,510)=4.68, p<.001 ; \beta_{\mathrm{BFW}}$ $\left.=.10, p=.025, \mathrm{CI}[.02, .24] ; R^{2}=.06 ; \Delta R^{2}=.01\right)$. A step-wise regression of all three predictors indicated that the belief in free will was the strongest predictor for both the course grade and the semester GPA.

We also tested for possible interactions between the predictors. The interaction between the belief in free will and trait self-control was found to be a significant predictor of course performance $\left(F(7,606)=4.06, p<.001 ; \beta_{\text {interaction }}=1.98, p=.048 ; \beta_{\mathrm{BFW}}=2.05, p=.041 ; \beta_{\mathrm{SC}}=\right.$ $1.45, p=$ n.s.; $\left.R^{2}=.05\right)$. A simple slope analysis indicates that when trait self-control is high $(+1$ standard deviation), the slope for the relationship between the belief in free will and performance 
is positive $($ slope $=.31, t(610)=2.50, p<.001$, CI $[.07, .55])$. However, when trait self-control is low $(-1$ standard deviation), the slope is no longer positive (slope $=.00, t(610)=-.03, p=\mathrm{n} . \mathrm{s}, \mathrm{CI}$ $[-.24, .24])$. Figure 1 plots the interaction, indicating that the belief in free will predicts a higher final score for those who scored high in trait self-control. However, no interaction was found for the overall GPA $\left(\beta_{\text {interaction }}=.04, \mathrm{p}=.423 \mathrm{~ns}\right)$. Controlling for trait self-control did not affect the positive relationship between the belief in free will and overall GPA.

In summary, Study 2 supported the hypothesis that a stronger belief in free will predicts better academic performance in real-life academic settings measured by course grades and semester GPA. The belief in free will was the only measure to significantly predict both course and semester grades. Its effect on academic achievement was strongest compared with trait selfcontrol and implicit theories. Controlling for trait self-control and implicit theories did not affect the relationship between the belief in free will and academic achievement.

\section{General Discussion}

Two studies supported the importance of the belief in free will in predicting academic performance. In Study 1, the belief in free will predicted positive performance in a short welldefined academic type task of checking spelling mistakes. In Study 2, the findings were replicated in an examination of real-life academic performance of undergraduates at a university, which showed that those who held stronger beliefs in free will performed better overall. The effect of the belief in free will was stronger than that of trait self-control and implicit theories, both considered powerful predictors of positive outcomes in life, and the relationship between the belief in free will and performance persisted when controlling for these two factors. 
Increasing evidence suggests that the belief in free will is more than an implicit, abstract, or philosophical belief and that it holds important implications for both cognition and behavior. Research emerging from the bridge between social psychology and experimental philosophy has linked the belief in free will with the fundamental social concepts of moral responsibility, prosociality, and accountability, as well as with the key factors for the self, such as motivation, self-regulation, choice, learning, and goal pursuit. Our findings extend the current literature on the positive behavioral implications of the belief in free will (reviewed in Baumeister \& Monroe, 2014) by demonstrating that the belief in free will is predictive of real-life behavior for students in academic settings.

Furthermore, we provided evidence that the belief in free will predicted academic performance on par and beyond the well-established predictors of trait self-control and implicit theories. We argued that the belief in free will encompasses a wider view of the person as a capable and active agent who is free to choose and pursue his/her own path. Results of examining the relationship between the belief in free will and other constructs demonstrated that those who believed in free will reported seeing categories (kind of person and intelligence) as more malleable and reported higher trait self-control. However, the weak correlations and the results of the pretest indicate that the belief in free will is meaningfully distinct from implicit theories and trait self-control. Interestingly, the belief in free will and trait self-control interacted, such that the best performance was achieved when both trait self-control and the belief in free will were high. This result suggests that the exertion of self-control to control one's impulses requires the volitional choice to do so (Baumeister, 2008) and the choice to exert control depends on the psychological resources to execute (Stillman et al., 2010). Thus, the belief in free will can 
be conceptualized as the freedom to choose the direction, whereas trait self-control facilitates the pursuit of this direction over time.

The findings in Study 1 that the belief in free will is predictive of performance in simple tasks without any reward is revealing. Previous literature has shown that the belief in free will is related to neural error detection (Rigoni et al., 2014; Rigoni et al., 2013) and the ability to learn from one's own mistakes (Stillman \& Baumeister, 2010), and our findings demonstrate that these effects translate to better performance in related academic tasks.

Over the years, the literature has offered a wide array of predictors for academic achievement, yet the demonstration of the predictive powers of beliefs holds a special promise as beliefs are often construed and affected by the environment and could be therefore be guided or influenced through careful interventions. Other well-studied predictors such as personality traits and intelligence are considered significantly harder to affectively change and often introduce complex ethical considerations. Our research and that of implicit theories suggest that beliefs and mindsets do matter for academic achievement, and follow-up research could explore how these findings can be translated into meaningful intervention tools for helping students perform better.

\section{Limitations}

As with any study, the current work is not without limitations. Both studies are correlational, thereby preventing any causal interpretations. Belief activation studies generally result in weak or no effect for performance measures, yet it is possible that well-constructed interventions to change beliefs may result in lasting changes in performance (e.g., Paunesku et al., 2015). Future studies may examine how shifts in the belief in free will and interventions affect performance and academic achievement. 
The present investigation established the main effect of the relationship between the belief in free will and academic achievement, yet it is possible that there are a number of moderating factors that would affect this relationship. The results revealed a close link between trait self-control and the belief in free will with an interaction between the two constructs in predicting outcomes. Future research could probe more deeply into the exact nature of this relationship to further explain how the belief in free will and trait self-control wield a concerted influence in predicting positive outcomes. The belief in free will may also interact with external environmental factors, such as the degree of choice and autonomy given for individuals (Patall et al., 2008; Patall et al., 2010). Future studies may examine how different environmental factors interact with the belief in free will to affect outcomes.

\section{Conclusion}

Free will is not merely an abstract philosophical idea, but one that holds relevance for people in their lives. In the present investigation the belief in free will predicted positive implications for real-life academic performance, showing that those who held stronger beliefs in free will performed better on academic tasks and achieved better course grades throughout an academic semester. We bridge between the research on implicit theories and agentic beliefs to contribute to these emerging lines of research that demonstrate the important implications of mindsets and beliefs for everyday life outcomes. 


\section{References}

Alquist, J. L., Ainsworth, S. E., \& Baumeister, R. F. (2013). Determined to conform: Disbelief in free will increases conformity. Journal of Experimental Social Psychology, 49(1), 80-86. doi:http://dx.doi.org/10.1016/j.jesp.2012.08.015

Alquist, J. L., Ainsworth, S. E., Baumeister, R. F., Daly, M., \& Stillman, T. F. (2015). The making of might-have-beens: Effects of free will belief on counterfactual thinking. Personality and Social Psychology Bulletin, 41(2), 268-283. doi:10.1177/0146167214563673

Baumeister, R. F. (2008). Free will in scientific psychology. Perspectives on Psychological Science, 3(1), 14-19.

Baumeister, R. F., \& Monroe, A. E. (2014). Chapter one-recent research on free will: Conceptualizations, beliefs, and processes. Advances in Experimental Social Psychology, 50, 1-52.

Baumeister, R. F., \& Brewer, L. E. (2012). Believing versus disbelieving in free will: Correlates and consequences. Social and Personality Psychology Compass, 6(10), 736-745. doi:10.1111/j.17519004.2012.00458.x

Baumeister, R. F., Sparks, E. A., Stillman, T. F., \& Vohs, K. D. (2008). Free will in consumer behavior: Self-control, ego depletion, and choice. Journal of Consumer Psychology, 18(1), 4-13. doi:http://dx.doi.org/10.1016/i.jcps.2007.10.002

Brass, M., Lynn, M., Demanet, J., \& Rigoni, D. (2013). Imaging volition: What the brain can tell us about the will. Experimental Brain Research, 229(3), 301-312. doi:10.1007/s00221-013-3472-x

Brembs, B. (2011). Towards a scientific concept of free will as a biological trait: Spontaneous actions and decision-making in invertebrates. Proceedings of the Royal Society B: Biological Sciences, 278(1707), 930-939. doi:10.1098/rspb.2010.2325 
Burnette, J. L., O'Boyle, E. H., VanEpps, E. M., Pollack, J. M., \& Finkel, E. J. (2013). Mind-sets matter: A meta-analytic review of implicit theories and self-regulation. Psychological Bulletin, 139(3), 655.

Carey, J. M., \& Paulhus, D. L. (2013). Worldview implications of believing in free will and/or determinism: Politics, morality, and punitiveness. Journal of Personality, 81(2), 130-141. doi:10.1111/j.1467-6494.2012.00799.x

Chao, M. M., Hong, Y. Y., \& Chiu, C. Y. (2013). Essentializing race: Its implications on racial categorization. Journal of personality and social psychology, 104(4), 619.

Chernyak, N., \& Kushnir, T. (2014). The self as a moral agent: Preschoolers behave morally but believe in the freedom to do otherwise. Journal of Cognition and Development, 15(3), 453-464.

Chernyak, N., Kushnir, T., Sullivan, K. M., \& Wang, Q. (2013). A Comparison of American and Nepalese Children's Concepts of Freedom of Choice and Social Constraint. Cognitive science, 37(7), 1343-1355.

Crescioni, A. W., Baumeister, R. F., Ainsworth, S. E., Ent, M., \& Lambert, N. M. (2015). Subjective correlates and consequences of belief in free will. Philosophical Psychology, 1-23.

de Ridder, D. T. D., Lensvelt-Mulders, G., Finkenauer, C., Stok, F. M., \& Baumeister, R. F. (2012). Taking stock of self-control: A meta-analysis of how trait self-control relates to a wide range of 
behaviors. Personality and Social Psychology Review, 16(1), 76-99.

doi:10.1177/1088868311418749

Dennett, D. C. (2003). The self as a responding — and responsible—artifact. Annals of the New York Academy of Sciences, 1001(1), 39-50.

Duckworth, A. L., \& Seligman, M. E. (2005). Self-discipline outdoes IQ in predicting academic performance of adolescents. Psychological Science, 16(12), 939-944.

Dweck, C. (2006). Mindset: The new psychology of success. Random House.

Dweck, C. S. (2008). Can personality be changed? The role of beliefs in personality and change. Current Directions in Psychological Science, 17(6), 391-394.

Dweck, C. S. (2012). Mindset: How you can fulfil your potential. Hachette UK.

Dweck, C. S. (2014). Mindset: How you can fulfil your potential. Constable \& Robinson Ltd.

Dweck, C. S., Chiu, C., \& Hong, Y. (1995). Implicit theories and their role in judgments and reactions: A word from two perspectives. Psychological Inquiry, 6(4), 267-285.

Dweck, C. S. (1999). Self-theories: Their role in motivation, personality, and development. New York, NY, US: Psychology Press.

Dweck, C. S., \& Leggett, E. L. (1988). A social-cognitive approach to motivation and personality. Psychological Review, 95(2), 256-273. doi:10.1037/0033-295X.95.2.256

Dweck, C. S., \& Molden, D. C. (2008). 4 self-theories: The construction of free will. In John Baer, James C. Kaufman \& Roy F. Baumeister (Eds.), Are we free?: Psychology and free will, 44. Oxford University Press.

Feldman, G., Baumeister, R. F., \& Wong, K. F. E. (2014). Free will is about choosing: The link between choice and the belief in free will. Journal of Experimental Social Psychology, 55(0), 239-245. doi:http://dx.doi.org/10.1016/j.jesp.2014.07.012 
Fries, S., Dietz, F., \& Schmid, S. (2008). Motivational interference in learning: The impact of leisure alternatives on subsequent self-regulation. Contemporary Educational Psychology, 33(2), 119133. doi:http://dx.doi.org/10.1016/j.cedpsych.2007.10.001

Greve, W. (2001). Traps and gaps in action explanation: Theoretical problems of a psychology of human action. Psychological Review, 108(2), 435.

Grund, A., Brassler, N. K., \& Fries, S. (2014). Torn between study and leisure: How motivational conflicts relate to students' academic and social adaptation. Journal of Educational Psychology, 106(1), 242-257. doi:10.1037/a0034400

Haggard, P., Mele, A., O’Connor, T., \& Vohs, K. D. (2010). “Lexicon of key terms.” big questions in free will project. Retrieved from http://www.freewillandscience.com

Hong, Y., Chiu, C., Dweck, C. S., Lin, D. M., \& Wan, W. (1999). Implicit theories, attributions, and coping: A meaning system approach. Journal of Personality and Social Psychology, 77(3), 588599. doi:10.1037/0022-3514.77.3.588

Hume, D. (1748). An enquiry concerning human understanding.

Kant, I. (1788/1997). Critique of practical reason.

Kushnir, T. (2012). Developing a concept of choice. Advances in child development and behavior, 43, 193-218.

Kushnir, T., Wellman, H. M., \& Chernyak, N. (2009). Preschoolers' understanding of freedom of choice. In Proceedings of the Thirty-First Annual Conference of the Cognitive Science Society (pp. 8792).

Lee, J. J., Gino, F., \& Staats, B. R. (2014). Rainmakers: Why bad weather means good productivity. Journal of Applied Psychology, 99(3), 504-513. doi:10.1037/a0035559 
Lynn, M. T., Van Dessel, P., \& Brass, M. (2013). The influence of high-level beliefs on self-regulatory engagement: evidence from thermal pain stimulation .Frontiers in psychology, 4.

Mayes, S. D., Calhoun, S. L., Bixler, E. O., \& Zimmerman, D. N. (2009). IQ and neuropsychological predictors of academic achievement. Learning and Individual Differences, 19(2), 238-241.

Monroe, A. E., \& Malle, B. F. (2010). From uncaused will to conscious choice: The need to study, not speculate about people's folk concept of free will. Review of Philosophy and Psychology, 1(2), 211-224.

Nichols, S. (2004). The folk psychology of free will: Fits and starts. Mind and Language, 19(5), 473-502.

Nietzsche, F. (1886/1966). Beyond good and evil. Basic Writings of Nietzsche.179-1968.435.

Patall, E. A., Cooper, H., \& Robinson, J. C. (2008). The effects of choice on intrinsic motivation and related outcomes: a meta-analysis of research findings.Psychological bulletin, 134(2), 270.

Patall, E. A., Cooper, H., \& Wynn, S. R. (2010). The effectiveness and relative importance of choice in the classroom. Journal of Educational Psychology,102(4), 896.

Paulhus, D. L., \& Carey, J. M. (2011). The FAD-Plus: Measuring lay beliefs regarding free will and related constructs. Journal of Personality Assessment, 93(1), 96-104.

Paunesku, D., Walton, G. M., Romero, C., Smith, E. N., Yeager, D. S., \& Dweck, C. S. (2015). Mind-set interventions are a scalable treatment for academic underachievement. Psychological Science, doi:10.1177/0956797615571017

Rakos, R. F., Steyer, K. R., Skala, S., \& Slane, S. (2008). Belief in free will: Measurement and conceptualization innovations. Behavior and Social Issues, 17(1), 20-39.

Rigoni, D., Kühn, S., Gaudino, G., Sartori, G., \& Brass, M. (2012). Reducing self-control by weakening belief in free will. Consciousness and cognition,21(3), 1482-1490. 
Rigoni, D., Kühn, S., Sartori, G., \& Brass, M. (2011). Inducing disbelief in free will alters brain correlates of preconscious motor preparation the brain minds whether we believe in free will or not. Psychological Science, 22(5), 613-618.

Rigoni, D., Wilquin, H., Brass, M., \& Burle, B. (2013). When errors do not matter: Weakening belief in intentional control impairs cognitive reaction to errors. Cognition, 127(2), 264-269.

Rigoni, D., \& Brass, M. (2014). From intentions to neurons: Social and neural consequences of disbelieving in free will. Topoi, 33(1), 5-12. doi:10.1007/s11245-013-9210-y

Rigoni, D., Pourtois, G., \& Brass, M. (2014). 'Why should I care?' challenging free will attenuates neural reaction to errors. Social Cognitive and Affective Neuroscience, doi:10.1093/scan/nsu068

Rohde, T. E., \& Thompson, L. A. (2007). Predicting academic achievement with cognitive ability. Intelligence, 35(1), 83-92.

Roskies, A. (2006). Neuroscientific challenges to free will and responsibility. Trends in Cognitive Sciences, 10(9), 419-423.

Sarkissian, H., Chatterjee, A., De Brigard, F., Knobe, J., Nichols, S., \& Sirker, S. (2010). Is belief in free will a cultural universal? Mind \& Language, 25(3), 346-358.

Seligman, M. E., Railton, P., Baumeister, R. F., \& Sripada, C. (2013). Navigating into the future or driven by the past. Perspectives on Psychological Science, 8(2), 119-141.

Stephens, N. M., Townsend, S. S. M., Markus, H. R., \& Phillips, L. T. (2012). A cultural mismatch: Independent cultural norms produce greater increases in cortisol and more negative emotions 
among first-generation college students. Journal of Experimental Social Psychology, 48(6), 13891393. doi:http://dx.doi.org/10.1016/j.jesp.2012.07.008

Stillman, T. F., Baumeister, R. F., Vohs, K. D., Lambert, N. M., Fincham, F. D., \& Brewer, L. E. (2010). Personal philosophy and personnel achievement: Belief in free will predicts better job performance. Social Psychological and Personality Science, 1(1), 43-50.

Stillman, T. F., \& Baumeister, R. F. (2010). Guilty, free, and wise: Determinism and psychopathy diminish learning from negative emotions. Journal of Experimental Social Psychology, 46(6), 951-960.

Stillman, T. F., Baumeister, R. F., \& Mele, A. R. (2011). Free will in everyday life: Autobiographical accounts of free and unfree actions. Philosophical Psychology, 24(3), 381-394.

Tangney, J. P., Baumeister, R. F., \& Boone, A. L. (2004). High self-control predicts good adjustment, less pathology, better grades, and interpersonal success. Journal of Personality, 72(2), 271-324.

Vohs, K. D., \& Schooler, J. W. (2008). The value of believing in free will encouraging a belief in determinism increases cheating. Psychological science,19(1), 49-54.

Yeager, D. S., \& Dweck, C. S. (2012). Mindsets that promote resilience: When students believe that personal characteristics can be developed. Educational Psychologist, 47(4), 302-314.

Yeager, D. S., Johnson, R., Spitzer, B. J., Trzesniewski, K. H., Powers, J., \& Dweck, C. S. (2014). The far-reaching effects of believing people can change: Implicit theories of personality shape stress, 
health, and achievement during adolescence. Journal of Personality and Social Psychology, 106(6), 867-884. doi:10.1037/a0036335

Wertenbroch, K., Vosgerau, J., \& Bruyneel, S. D. (2008). Free will, temptation, and self-control: We must believe in free will, we have no choice (Isaac B. Singer). Journal of Consumer Psychology, 18(1), 27-33. 
Tables

Table 1

Study 1 correlations

M SD Belief in Score Time

free will

\begin{tabular}{lccccc}
\hline Belief in free will & 68.34 & 19.62 & $(-)$ & \\
Task performance - score & 2.04 & .29 & $.20^{*}$ & $(-)$ & \\
Task performance - time & 2.63 & .29 & $-.20^{*}$ & $-.32^{* *}$ & $(-)$ \\
(not logged) & $(14.49)$ & $(4.35)$ & & & \\
\hline Age & 19.18 & .65 & -.09 & -.08 & -.12 \\
Gender ${ }^{\mathrm{a}}$ & - & - & .00 & .17 & -.05 \\
Hong Kong students & - & - & -.12 & $.20^{*}$ & .06 \\
Mainland China students & - & - & -.09 & $-.21^{*}$ & .15 \\
International students & - & - & $.24^{* *}$ & -.04 & $-.22^{*}$ \\
\hline Note. ${ }^{\text {a Gender is dummy coded }(0=\text { male, } 1=\text { female }) .}{ }^{*} p<.05, * * p<.01$. & \\
\hline
\end{tabular}


Table 2

Pretest correlations and reliabilities

\begin{tabular}{lll}
\hline & Belief in FW & Alpha \\
\hline Trait self-control & $.49^{* * *}$ & 0.81 \\
Implicit theories kind of person & -.15 & 0.65 \\
Implicit theories moral & -.13 & 0.69 \\
Implicit theories intelligence & $-.25^{*}$ & 0.72 \\
Implicit theories race & .03 & 0.30 \\
\hline Note: $* * * p<.001 ; * * . p<0.01 ; * . p<0.05$ & &
\end{tabular}


Table 3

Study 2 correlations and reliabilities

\begin{tabular}{|c|c|c|c|c|c|c|c|c|}
\hline & $\mathrm{M}$ & SD & $\begin{array}{l}\text { Belief in } \\
\text { free will }\end{array}$ & $\begin{array}{l}\text { Implicit } \\
\text { theories } \\
\text { general }\end{array}$ & $\begin{array}{l}\text { Implicit } \\
\text { theories } \\
\text { intelligence }\end{array}$ & $\begin{array}{l}\text { Self- } \\
\text { control }\end{array}$ & $\begin{array}{l}\text { Final } \\
\text { course } \\
\text { score }\end{array}$ & $\begin{array}{l}\text { Semester } \\
\text { GPA }\end{array}$ \\
\hline Belief in free will & 3.50 & .44 & $(.71)$ & & & & & \\
\hline Implicit theories general & 3.58 & .81 & $-.12 * *$ & (.84) & & & & \\
\hline Implicit theories intelligence & 3.60 & 1.11 & $-.24 * * *$ & $.41 * * *$ & $(.89)$ & & & \\
\hline Self-control & 2.87 & .49 & $.19^{* * *}$ & -.03 & $-.18 * * *$ & (.77) & & \\
\hline Final course grade & 0 & 1 & $.08^{*}$ & .03 & -.05 & $.09^{*}$ & $(-)$ & \\
\hline GPA & 2.86 & .57 & $.09^{*}$ & $.11 *$ & -.01 & .06 & $.73^{* * *}$ & $(-)$ \\
\hline Age & 18.90 & .80 & -.02 & .05 & .02 & -.02 & .01 & $.12^{* *}$ \\
\hline Gender $^{\mathrm{a}}$ & - & - & -.02 & .05 & .05 & -.01 & .05 & -.05 \\
\hline Hong Kong students & - & - & $-.19^{* * *}$ & $.09 *$ & .02 & $-.10^{*}$ & $-.09^{*}$ & $-.14^{* *}$ \\
\hline Mainland China students & - & - & -.01 & .07 & $.13 * *$ & .02 & $.15^{* * *}$ & $.17^{* * *}$ \\
\hline International students & - & - & $.27^{* * *}$ & $-.19 * * *$ & $-.18^{* * *}$ & $.10^{*}$ & -.04 & .01 \\
\hline
\end{tabular}

Note. ${ }^{a}$ Gender is dummy coded $(0=$ male, $1=$ female $) ;{ }^{*} p<.05 ; * * p<.01 ;{ }^{* * *} p<.001$; Alpha coefficients are presented on the diagonal. 


\section{Figures}

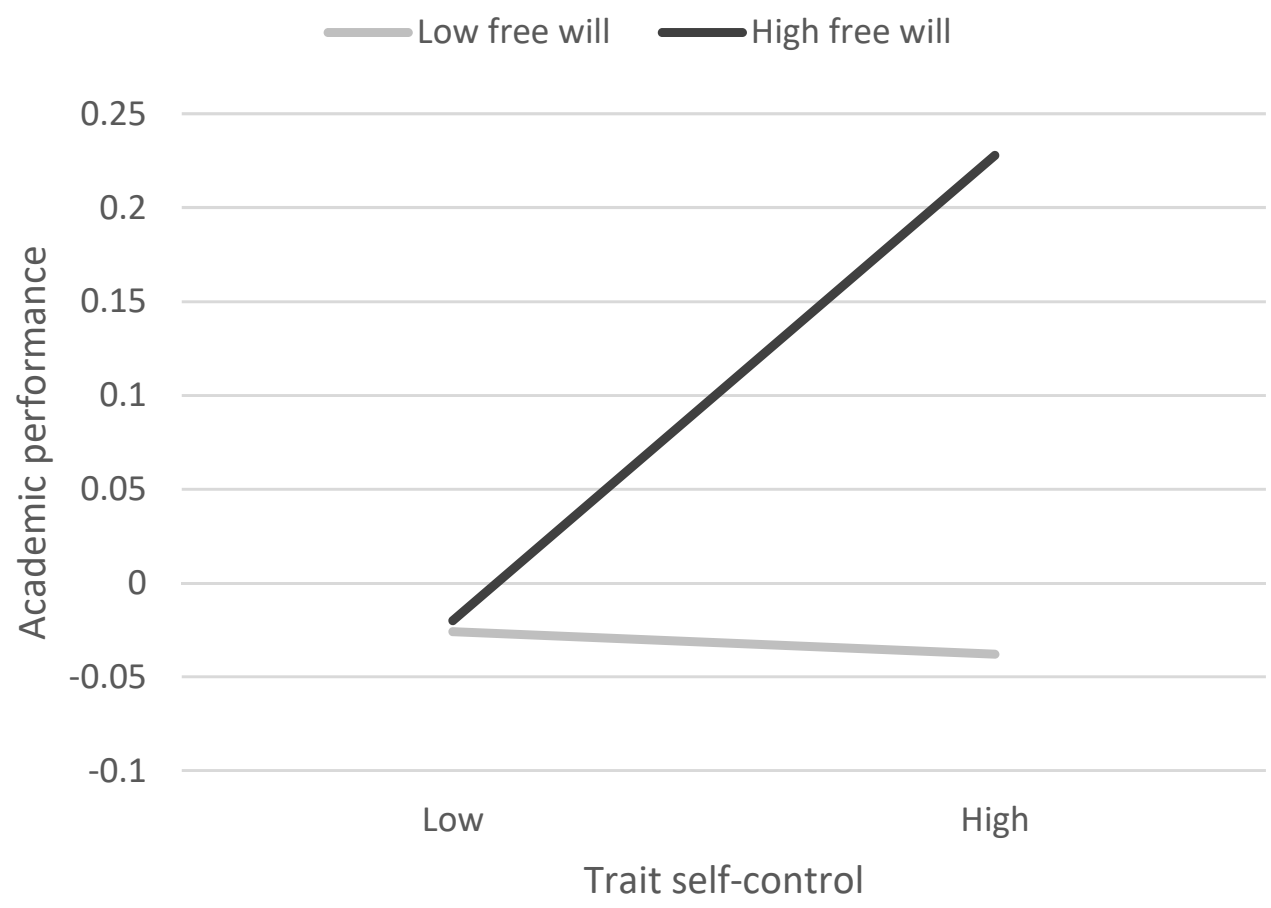

Figure 1. The interaction between the belief in free will and trait self-control in predicting academic performance in an undergraduate course. Low and high values were calculated as one standard deviation below and above mean. 